\title{
In-service education and training as experienced by registered nurses
}

\author{
TF Norushe, M Cur, Chief Professional Nurse, Health Services, Buffalo City \\ Municipality \\ D Van Rooyen, D Cur, Head of Department, Nursing Science, University of Port \\ Elizabeth \\ J Strumpher, D Cur, Professor of Nursing, University of Port Elizabeth
}

\section{Abstract}

Nursing is a dynamic profession that is subject to rapid changes in health care provision, hence the need for inservice training programmes for nurses. Newly employed registered nurses require in-service training in order to update them regarding the latest developments in nursing practice. The researcher noted that some newly appointed registered nurses were not competent in all aspects relating to their tasks. This could have been due to a knowledge deficit relating to either new developments or of the procedure relating to a specific task. In some institutions newly-appointed registered nurses on probation reported not receiving in-service training for six months or longer, yet they were still expected to perform their tasks efficiently.

The objectives of the study were to, firstly, explore and describe the experiences of registered nurses regarding in-service training programmes in their institutions and, secondly, to make recommendations to Nursing Service Managers relating to the development of effective inservice training programmes in their institutions. A qualitative, exploratory, descriptive design was implemented. Data was analysed using Tesch's descriptive approach (in Creswell, 1994:155).

Two main themes emerged, namely that registered nurses experienced in-service training programmes as inadequate and reacted negatively towards them. This article focuses on the experiences of registered nurses relating to in-service training programmes, as well as the formulation of guidelines to assist nursing service managers in the development of effective in-service training programmes.

KEY WORDS: In-service training programme; Development; Guidelines; Primary Health Care

\section{Opsomming}

Verpleegkunde is ' $n$ dinamiese professie wat aan vinnige veranderinge in gesondheidsorg lewering blootgestel word. Daarom bestaan daar ' $n$ behoefte aan indiensonderrig en opleidingsprogramme vir verpleegkundiges. Geregistreerde verpleegkundiges benodig indiensonderrig en opleiding sodat hulle betreffende die nuutste ontwikkelings in verpleegpraktyk op hoogte kan bly. Die navorser het opgemerk dat sommige geregistreerde verpleegkundiges nie in alle aspekte van wat verbandhou met hulle take in alledaagse praktyk, bevoeg is nie. Dit kan wees as gevolg van 'n kennisgebrek ten opsigte nuwe ontwikkelinge of prosedures ten opsigte van spesifieke take. In sommige instansies het voorwaardelik nuutaangestelde geregistreerde verpleegkundiges gerapporteer dat hulle nie indiensonderrig en opleiding vir ses maande of langer ontvang het nie en dat daar van hulle verwag word om hul take effektief uit te voer.

Die doelstellings van die studie was, eerstens, om die ervaringe van geregistreerde verpleegkundiges betreffende indiensonderrig en opleidingsprogramme by hulle instansie te eksploreer en te beskryf. Tweedens, om riglyne ter ondersteuning van verpleegdiensbestuurders om effektiewe indiensonderrig en opleidings programme te verseker, ontwikkel. ' $n$ Kwalitatiewe, eksplorerende en beskrywende ontwerp was geimplimenteer. Data was geanaliseer deur die gebruikmaking van Tesch se beskrywende benadering (in Creswell, 1994: 155)

Twee hooftemas het uitgekom, naamlik dat verpleegkundiges indiensonderrig en opleiding as onvoldoende ervaar en dat hulle daarop negatief gereageer het. Hierdie artikel fokus op die ervaringe van geregistreerde verpleegkundiges ten opsigte van indiensonderrig en opleidingsprogramme asook die formulering van riglyne ter ondersteuning van verpleegdiensbestuurders in die ontwikkeling van effektiewe indiensonderrig en opleidingsprogramme.

SLEUTELWOORDE: Indiensonderrig en opleidingsprogramme; Ontwikkeling; Geregistreerde verpleegkundiges; Verpleegdiensbestuurders. 


\section{Introduction and rationale}

High quality nursing care can only be a reality in an environment where registered nurses are kept up to date with modern developments by means of in-service training, which should be seen as an integral part of the work situation. Mellish and Brink (1990:377) state that one of the purposes of in-service training is to assure independent, thinking, competent, knowledgeable registered nurses who are capable of exercising educated judgement in the delivery of patient care. Nursing is a dynamic profession that is subject to rapid changes, hence the need for in-service training for nurses.

In-service training can be described as training that has been systematically planned, is carried out by a trainer within an institution and takes place during normal working hours. Booyens (1998:384) describes in-service training as the training of an employee while she/he is rendering a service to the clients in an institution and includes the following: training; updating knowledge; educating; standardising procedures; correcting shortcomings; keeping staff informed of company polices; motivating staff to develop both personally and professionally; informing the individual about the present requirements of the job.

The Labour Relations Act (Act 66 of 1995) makes it difficult for an employer to dismiss an employee on the basis of ineffectiveness unless the employer has taken specified steps to assist that employee in improving his/her performance.

This brings into focus the training and development in an institution. In evaluating the quality of standards, supervisors have to determine whether the shortcomings related to employee performances that require in-service training are due to misunderstanding, attitude, inadequacy in knowledge and skills or inefficient supervision. All identifiable variables related to shortcomings of employees have to be taken into consideration and the in-service training programmes of the institutions have to devote attention to these. The training and development of registered nurses should, therefore, be undertaken with a specific purpose in mind when a definite need with regard to competence has been identified.

It is vital for any institution to base its training and development philosophy on job-content training, management and leadership training. This conceptualisation indicates that all employees should get job-content training throughout their careers. Subordinates would be enabled, through job-content training, to gain basic skills that were not acquired in previous training, but which are required in the execution of their current duties, thus exposing them more to their functional areas.

A well-planned in-service training programme should facilitate the attainment of standards of care and help registered nurses to acquire the skills and knowledge necessary to fulfil their role expectations. The acquired knowledge should enable the registered nurses to be far more recep- tive and adaptable to changes in their roles and contribute to employee satisfaction and improve morale (Swansburg, 1995:164-167). It is in this light that in-service training in nursing has been identified as a necessary component of professional competence.

The researcher has noted that very few studies concerning the experiences of the registered nurse involved in the inservice training programmes have been documented. This study will focus on the in-service training education programmes that are conducted for the registered nurses in some of the Eastern Cape areas.

\section{Problem statement}

The researcher's interest in institutional in-service training programmes, as experienced by registered nurses, was initially stimulated through an awareness of the problems that registered nurses experienced with these, whether they were formal or informal. The researcher observed the many problems related to in-service training during the period that she was employed in the clinical field. The researcher noted that registered nurses were not always ready to fulfil all inherent functions related to their jobs, for example instead of implementing the Expanded Programme of Immunisation policy they were still utilizing the regime that was in place prior to 1994. Nurses may be unaware of either new developments or procedural approaches in the institution in which they are working. Newly appointed staff, who have been out of the field of clinical practice for some time, may lack skills and expertise and possess an inadequate knowledge base regarding new policies. In some health care institutions, newly appointed nurses on probation reported not receiving in-service training for six months or longer. Despite this, the nurses are still expected to perform their tasks expertly.

\section{Research questions}

The following questions arose regarding in-service training programmes:

- How do registered nurses experience the in-service training programmes provided by their institutions?

- How can the nursing service manager be guided in the development of in-service education programmes that are meaningful and which will be accepted positively by the registered nurses?

\section{Central statement}

The central statement of this research is that the insight obtained into the experience of registered nurses regarding the in-service training in their institutions will form the basis for the development of guidelines for the compilation of in-service training programmes for registered nurses.

\section{Objectives}

The objectives of this study were to:

- Explore and describe how registered nurses experi- 
ence in-service training in their institutions.

- Make recommendations to nursing service managers with regard to the compilation of effective in-service training programmes in their institutions.

\section{Definition of concepts}

\section{- In-service Training Programme}

In-service training is the training given by the employer to an employee to enable the individual to execute a specific activity efficiently. It is part of continuing education. Inservice training is deliberately planned to meet the needs of the employer in order to make up deficiencies in technical and scientific information in an employee, such as teaching of techniques and procedures that the employee has to execute in her/his job (Douglas, 1996:281).

\section{- $\quad$ Registered nurse}

An individual authorized and capable of practising nursing or midwifery independently by virtue of registration in terms of section 16 of the Nursing Act, 1978 (Act 50 of 1978). Such a person is accountable for prescribing, supervising and carrying out of the nursing regime, coordinating and integrating the multi disciplinary therapeutic regime based on diagnosing the needs and demands of a unique patient in a unique situation, establishing and managing a safe and adequate environment for patient care, assessing patient care situations based on scientific principles and skills, making nursing diagnoses and taking responsibility for her actions (SANC Terminology List, 1994:5; Kotzè, 1998:10).

\section{- $\quad$ Nursing Service Manager}

The Nursing Service Manager (within the context of this study)is the registered nurse who directs and supports personnel, co-ordinates nursing care to achieve desired outcomes and is responsible for creating an environment where nursing practice thrives (compare Potter and Perry, 2001:65)

\section{Research design and method}

The study design was qualitative, exploratory, descriptive, contextual and phenomenological in nature. The study was qualitative as it endeavoured to study the in-service training programmes as experienced by registered nurses in their institutions. Tutty, Rothery and Grinnel (1996:4) and Mason (1996:4) agree that a qualitative research approach can be used to study the person in her/his natural environment in order to find out what captivates or distresses them. It focuses on exploring their life experiences.

The study was exploratory as it focussed on how registered nurses experience the in-service training programmes in their particular institutions. According to Talbot (1994:90), an exploratory study aims to uncover the relationships and dimensions of a phenomenon.

The study was descriptive as the experiences of the regis- tered nurses relating to in-service training programmes were described. Burns and Grove ( 1997:38) contend that descriptive research provides an accurate account or portrayal of characteristics of a particular individual, situation or group.

The proposed study was also phenomenological, as the registered nurses who had experienced the described situation were questioned with regard to their experiences.

\section{Research Method}

The research study was structured into two phases, namely: Phase One: Data collection and analysis

Phase Two: Developing guidelines

The researcher used the two phases to ensure clarity and the study was discussed as such. Phase One will now be discussed:

\section{Research Population and Sampling}

The researcher in this study used purposive sampling to identify the participants for inclusion in the study in order to meet the requirements of sampling criteria. Purposive sampling is a perfect method to use in exploratory research when the researcher wishes to do an in-depth investigation in order to gain a deeper understanding of a certain phenomenon. De Vos (1998:198) states that purposive sampling is entirely based on the judgement of the researcher, as the sample comprises elements which contain the most characteristics or attributes of the population. Contextuality is enhanced with purposive sampling.

In this study, the research population comprised registered nurses working in the East London Health District in a Primary Health Care setting. The registered nurses were afforded the opportunity to participate in the study once the necessary consent had been obtained from the Provincial Department of Health and heads of relevant institutions. They were asked to voluntarily place their names and contact telephone numbers in a sealed box that was available in their clinics for two weeks. The researcher selected names from the box and appointments for phenomenological interviews were subsequently made.

\section{Sampling Procedure}

Saturation of data determined the sample size (Streubert and Carpenter 1995:24), which finally comprised nine registered nurses. The research participants were required to be representative of the three main cultural groups residing in the East London Health District, as well as of both genders. Other criteria for selection included being:

- A registered nurse with at least three months experience working in a Primary Health Care setting in the East London Health District.

- A recipient of in-service training programmes during this period.

- Able to communicate in either English or Xhosa.

- Willing to participate.

\section{Data Collection}

Polit and Hungler (1997:454) define data collection as a 
method of gathering information in order to address a research problem. Different forms of data collection used in this study will now be discussed.

\section{Interviewing}

Data was collected by means of phenomenological interviews, a method that gave the registered nurses the freedom to talk and describe their experiences of the in-service training programmes in their institutions (Burns and Grove, 1993:66). The interviews were conducted in the registered nurses' private offices in their institutions. All the selected participants were asked the same question according to specific interviewing techniques.

"Tell me, how do you experience the in-senvice training programmes in your institution?"

Each interview was audio taped and transcribed verbatim.

\section{Field Notes}

Field notes, based on observations made during the interviews, were taken (Field and Morse, 1996:913).

\section{Data Analysis}

The interviews were transcribed within twenty-four hours of being conducted and, together with the field notes, formed the database for the research. The aim of data analysis is to identify themes emerging from the data (Brink. 1994:15). The data collected was analysed with regard to how the in-service training programmes were experienced by the registered nurses in their institutions. Tesch's method of analysis (in Creswell 1994:153-155) was used to organise the content of the interviews objectively and systematically. After reading through all the transcripts of the participants, a list of topics was noted and similar topics clustered together. The identified themes and sub-themes were coded and categorised. Those relating to each other were amalgamated. Interrelationships were drawn amongst the categories. The analysis continued until themes were saturated and no new themes surfaced.

The raw data comprising the transcribed interviews and the field notes were sent to an independent coder with a protocol containing the guidelines for data analysis for verification. The independent coder identified themes and categories. A consensus discussion between the independent coder and the researcher was held to finalize the identified themes. This is one of the appropriate ways to ensure accuracy and trustworthiness of the results (De Vos, 1998:345).

\section{Literature Control}

A literature control was then done to verify the findings (Poggenpoel, 1993:3). The aim of the literature control was to determine whether the identified themes had been obtained by other researchers. This was accomplished by comparing the identified themes with other research recently undertaken (De Vos, 1998:345).

\section{Trustworthiness}

Trustworthiness of this study was ensured by using the criteria suggested by Guba (in Krefting, 1991:2 14-217). This model is divided into four criteria of trustworthiness, namely: truth value; applicability; consistency and neutrality (see table I).

\section{Ethical considerations}

The researcher made it a priority to ensure protection of the rights of participants in this study by ensuring that the ethical principles, based on the guidelines of the South African Society for Nursing Researchers (1996:74-75), were considered throughout the study. These include maintenance of confidentiality and anonymity, avoidance of harm and obtaining of informed consent from the institutions involved, as well as from each participant. The participants were given the option to withdraw from the research at any time. The tapes used during the interviews were deleted by the researcher as soon as the study was completed. The researcher ensured the quality of the research by informing participants fully about the goal of the study, the method of research and what was expected of them. She explained how results would be used and published and that confidentiality and anonymity would be maintained throughout.

\section{Research findings}

The following is a study of the results. All statements have been supported by quotes from the original text. A literature control was done to verify the findings. Results of the research are summarised in table 2 .

\section{Discussion of research findings}

The following is a summary of conclusions drawn from results.

\section{Theme 1: Registered nurses experienced in-service training as inadequate}

Participants perceived the existing in-service training programmes as inadequate. This contributed to decreased work satisfaction. Although in-service training programmes were available in some institutions, they were not effectively implemented for a number of different reasons. For example, they failed to adhere to the institutional in-service training programme plan. As a participant commented:

"-we draw up a monthly roster for in-service - we find it difficult to adhere to it sometimes, because in the clinics we have essential services-".

Mellish and Lock (1992:172) state that when realistic inservice training programmes are drawn up, care should be taken to avoid clashes with service needs.

Registered nurses, because of these time limitations, pre- 


\begin{tabular}{|c|c|c|}
\hline STRATEGY & CRITERIA & APPLICABILITY \\
\hline \multirow[t]{6}{*}{ Credibility } & $\begin{array}{l}\text { Prolonged and varied field } \\
\text { experience. }\end{array}$ & $\begin{array}{l}\text { Maintained through conducting phenomenological inter- } \\
\text { views until data saturation. } \\
\text { Both the supervisor and co-supervisor have experience re- } \\
\text { lating to qualitative research. } \\
\text { Researcher's vast working experience in a Primary Health } \\
\text { Care setting and in implementing in-service training pro- } \\
\text { grammes. }\end{array}$ \\
\hline & Triangulation & $\begin{array}{l}\text { Ensured through conducting interviews, field notes and lit- } \\
\text { erature control. } \\
\text { Data analysis done by researcher and independent coder. } \\
\text { Use of articles, journals, internet searches and CD-ROMS } \\
\text { (Medline) access to data and literature control. }\end{array}$ \\
\hline & Reflexivity & Ensured through taking of field notes. \\
\hline & Peer examination. & $\begin{array}{l}\text { Analysis by an independent coder, who is a nurse, assisted } \\
\text { with data analysis. } \\
\text { Primary Health Care nurses in the clinical practice field were } \\
\text { asked to review the proposed guidelines for in-service train- } \\
\text { ing. }\end{array}$ \\
\hline & Member checking & $\begin{array}{l}\text { Follow-up interviews were held with participants after the } \\
\text { themes were identified. } \\
\text { Member checking done through undertaking literature con- } \\
\text { trol. }\end{array}$ \\
\hline & Authority of researcher & $\begin{array}{l}\text { Supervision done by two nurse researchers, one holding a } \\
\text { Doctoral degree and the other one pursuing the same de- } \\
\text { gree in the field of nursing. } \\
\text { Both are well versed in qualitative research. They supported } \\
\text { the researcher's capabilities and supervised her ethics. }\end{array}$ \\
\hline Applicability & Nominated sample & $\begin{array}{l}\text { Purposive sampling. } \\
\text { Complete description of the methodology used. }\end{array}$ \\
\hline \multirow[t]{4}{*}{ Consistency } & Dense description & $\begin{array}{l}\text { Means that a complete description of the design and the } \\
\text { method and accompanying literature control was done. }\end{array}$ \\
\hline & Stepwise replication & $\begin{array}{l}\text { An independent coder was used to analyse data and dis- } \\
\text { cuss findings with the researcher. }\end{array}$ \\
\hline & Triangulation & $\begin{array}{l}\text { The researcher obtained expert guidance from qualitative } \\
\text { nurse researchers. } \\
\text { Data collection was done through interviewing. Field notes } \\
\text { were kept and literature control completed. }\end{array}$ \\
\hline & Peer group examination & $\begin{array}{l}\text { Research was done with study leaders with relevant quali- } \\
\text { tative research expertise. } \\
\text { An independent coder was used to reach consensus on } \\
\text { identified themes. } \\
\text { Primary Health Care nurses in the clinical practice field were } \\
\text { asked to review the proposed guidelines for in-service train- } \\
\text { ing. }\end{array}$ \\
\hline \multirow[t]{3}{*}{ Neutrality } & Field notes & Field notes were taken during interviews. \\
\hline & Reflexivity & As discussed above. \\
\hline & Triangulation & As discussed above. \\
\hline
\end{tabular}




\section{Table 2 An overview of the main themes and sub-themes of the results of registered nurses' experiences in relation to the organisation of in-service training programmes}

\begin{tabular}{|l|l|}
\hline MAINTHEMES & \multicolumn{1}{|c|}{ SUB-THEMES } \\
\hline $\begin{array}{l}\text { 1. Registered nurses experience in-service } \\
\text { training as inadequate }\end{array}$ & $\begin{array}{l}1.1 \text { Availability of in-service training programmes. } \\
\text { Some facilities do not provide in-service training programmes. } \\
\text { When an in-service training programme exists, it addresses the } \\
\text { orientation of new employees only. } \\
1.2 \text { In-service training programmes are planned and implemented in a } \\
\text { haphazard fashion. } \\
1.3 \text { In-service training programmes are inadequately evaluated. } \\
1.4 \text { Supervisors lack effective leadership qualities. }\end{array}$ \\
\hline $\begin{array}{l}\text { 2. Registered nurses attending in-service } \\
\text { training programmes experienced these } \\
\text { negatively }\end{array}$ & $\begin{array}{l}2.1 \text { Registered nurses experienced resistance due to the fact that some } \\
\text { nurses with less qualifications and experience were teaching them. } \\
2.2 \text { Registered nurses experienced a lack of support by supervisors re- } \\
\text { lated to their in-service training needs. }\end{array}$ \\
\hline
\end{tabular}

ferred to utilize teachable moments:

"_-in-service is a very important thing__ whatever format it takes, be it formal or informal_I prefer the informal approach, the use of teachable moment."

Lowane (in Bezuidenhout, Kock and Netshandama, 1999:4652) supports the view of utilizing teachable moments as the best method available to ensure that registered nurses are competent, interested and up to date. As making use of teachable moments did not intrude significantly upon the time nurses were available to clients, this approach was preferred by the nurses.

It was also highlighted that in-service training programme planners made the common mistake of assuming that they knew what their counterparts/the registered nurses needed to learn.

"-they don't involve, they just sit down themselvesthey will draw up their programme for a month-they-just decide for you —— "

Participants experienced in-service training programmes as addressing the needs of orientation of new personnel only. They stated that the in-service training programmes that did exist were often haphazardly designed as orientation programmes and did not meet their needs. They revealed that they were orientated only in regard to the environment and buildings. They experienced difficulties such as communicating with their supervisors and were not provided with knowledge to do their jobs. This viewpoint was reflected in the following statement:

"Mv very first experience of the clinic was orientation to the building, for example the kitchen, dispensary, consulting room and toilets. I was shown my room, consulting room and was left to fend for myself I was told if I do not understand something I should ask."

This problem was identified in the study done by Melia
( 1987 in Maben and Clarke, 1996:28-31) when exploring how diplomats fared after qualification. In their own words the diplomats were "-thrown in at the deep end-sense of being alone —on your own-."

This may lead to unsuccessful in-service training programmes as the registered nurses' learning needs may be different from those perceived by their supervisors and programme planners. This may again lead to decreased or non-existent participation in the in-service training programmes (Swansburg, 1996: 524). Rath, Boblin-Cummings, Parrot and Parsons (1996:12-15) state that if in-service training does not address the needs of the learners, it often results in disappointment about unmet learning objectives, wasted expenses, or inability to incorporate the information into practice.

\section{Theme 2: The participants attending in-service training programmes experienced these programmes negatively}

The supervisors and instructors responsible for planning and implementing in-service training programmes lacked effective leadership qualities.

- Highly qualified registered nurses strongly objected to being given in-service training from less qualified nurses.

This is consistent with the descriptive study measuring nurses' attitudes towards the nursing process in the United Kingdom where it was noted that negativity increased with the nurse's academic achievements (Bush Kitson in Savage 1993:19-21).

- $\quad$ Older registered nurses, the training of whom is sometimes perceived as being inferior, often objected to any form of in-service training from younger nurses. An Australian study done by Puetz (in Kersaitis 1997:135- 
137) to explore the attitudes and participation of registered nurses in continuing professional education found that a core of nurses exists that refuses to avail themselves of continuing professional education unless forced to do so.

- $\quad$ Prior knowledge and expertise of some registered nurses were not considered by their supervisors.

Douglas (1996:283) supports the notion that experience is the best teacher. Individuals with varied experience and expertise in relevant topics should be utilised (Rath et al, 1996:12-15).

- Other registered nurses felt strongly about the lack of support from their supervisors, since they felt illequipped to perform certain skills due to the fact that standardized protocols and procedures were not demonstrated to them.

Nel and Haasbroek (in Gerber, Nel and Van Dyk, 1998:452) contend that all newly employed, promoted or transferred employees should receive induction training. An effective induction programme, which should be strictly monitored by the supervisors/managers, helps reduce the adjustment problems by creating a sense of security, confidence and belonging for them (Carrell, Elbert, Hatfield, Grobler, Marx and Van der Schyff, 1998:208-209).

As a result of these, the participants experienced a wide range of emotions ranging from frustration, anger, stress and anxiety to hopelessness. They tended to use coping mechanisms such as projection, suppression, rationalisation and emotional distancing or withdrawal to deal with the stress that the situation evoked. Du Rand and Viljoen (1999:10) contend that people placed in stressful situations often react by becoming anxious and using many varied ways of coping.

As a result of the rapid changes in the health care system, as well as changing roles in nursing. nurses have lifelong learning needs. Knowledge and skills gained during basic nursing training programmes become insufficient as nursing is influenced continuously by latest developments. This emphasises the need for in-service training programmes. Supervisors should play a critical role in the support and planning of in-service training programmes in their institutions. Individuals generally like to share knowledge and expertise if given the chance to do so. It is, therefore, imperative for the supervisors to provide nurses who have the relevant expertise with the opportunity to demonstrate their skills and share information with others (Swansburg, 1996:532).

\section{Guidelines to improve in-service training programmes}

The following strategies were proposed as guidelines to assist in the planning, implementation and evaluation of effective in-service training programmes:

\footnotetext{
- Identification and assessment of training needs of registered nurses
}

The training needs of both the registered nurses and providers of in-service training programmes should be addressed in the short and long term so that maximum efficiency and value for money can be obtained. The methods of needs assessment include the following: questionnaires or surveys; observations of registered nurses in their working environments using standardised guides; interviews to collect data; open group meetings; competencies model whereby individual needs are discovered by developing a series of statements which identify expected behaviour or performance; performance appraisal; incident reports, quality assurance and audits (Sullivan and Decker, 1992:305; Swansburg, 1996:524). Evidence of the results should be available for perusal by the registered nurses.

- Joint planning of in-service training programmes Successful in-service training programmes depend on active participation and involvement of registered nurses (Booyens, 1998:641). An in-service training committee should be established and goals set. The success of inservice training programmes will be enhanced when criteria for selection of content includes consideration of the qualifications of instructors. The topics for inclusion must be generated from the operational problems, for example implementation of one of the new health programmes (eg new Tuberculosis treatment) identified by both the nurses and the supervisors and the programme planners (Cotton, 1997:43).

\section{- Considering unit conditions}

The conditions of the units, eg staff shortages, workload and unit peak busyness time, should be taken into consideration. In-service training should also work in conjunction with trainee programmes. They should also focus on management of workloads and designing of realistic job descriptions (Booyens, 1998:202).

\section{- The role of management in relation to in-service} training programmes

Supervisors should create a climate of trust and open communication between themselves and staff members. This should be based on a participative rather than a laissezfaire or an autocratic type of leadership. This is reflected in a bottom up approach where the information must come from the registered nurses through needs identification for in-service training programmes.

\section{- Selection of competent instructors for in-service training programmes}

The instructors appointed to present in-service training should have a more in-depth understanding of the subject than their audience. They should be aware of the problems encountered by registered nurses when trying to integrate theory and practice. They should also support and facilitate change in institutions (Swansburg, 1996:523)

\section{- Improving teaching strategies of instructors}

Registered nurses and programme planners should be able, and have the opportunity, to demonstrate psychomotor skills when performing their duties, for example the new 
administration of BCG intradermal injection requires a special skill regarding positioning of the needle. They should also be competent in the transfer of knowledge to others. Teaching strategies should include a variety of methods, for example formal lectures, demonstrations, group discussions, role plays, learning games, use of the teachable moment, problem-solving, nursing and medical rounds, teaching through supervision, case studies and learning by doing (Douglas, 1996:291).

\section{- Encouraging the principles of adult education}

The programme planners and the managers should ensure that the in-service trainingenvironment is conducive to learning. The following adult education principles are prerequisites within in-service training programmes: readiness of registered nurses to learn, motivation to learn, active participation, useful knowledge by exposing learners to appropriate knowledge and training rather than theoretical notions, an individual pace of learning and individual differences. Both the in-service training planners and management should encourage critical thinking skills as part of self-directed learning for the registered nurses (Swansburg, 1995:108-110: Case, 1996:146-156).

\section{- Improve effective leadership qualities}

The nurse managers should practise nurse advocacy by promoting effective in-service training programmes. They should enhance individual motivation for in-service training programmes by collecting information about registered nurses' present effectiveness on the job and share it (Booyens, 1998: 507). In an attempt to become more relationship-focussed more attention could be given to discussing the problem in hand, for instance a more effective way of implementing in-service training programmes instead of constantly focussing on what is not working. Successful in-service training programmes depend on team work, mutual problem-solving, team learning and shared goal setting.

- $\quad$ Reinforcing interpersonal relationships with registered nurses during in-service training programmes

A humane and personalized working environment for registered nurses during in-service training programmes should be provided. Strategies such as interpersonal training skills, assertiveness training; conflict management and stress management can be used by registered nurses in relation to in-service training programmes to establish collaborative relations (Booyens, 1995: 54).

Cultural diversity among staff should be acknowledged, as it is part of uniqueness. Enhanced self-esteem could lead to improved professional performance. The dignity of all nurses involved in a multi-cultural situation should be respected in order to promote the development of a therapeutic relationship. Cultural sharing amongst all staff should be encouraged through formal in-service training programmes. The management should insist upon in-service training programmes that focus on issues of pluralism and cultural diversity so as to foster cohesiveness and collegiality within a multi-cultural health care setting (Champinha-Bacote, Yahle and Langendamp, 1996: 60-63).
- Improving personal worth in relation to in-service training programmes

The registered nurses, nurse managers and programme planners should empower one another with valuable insights and support in relation to the identification of needs of individual registered nurses. Such empowerment improves the registered nurses' individual talents in the in-service training programmes and heightens co-operation and improves personal worth in relation to in-service training programmes (Burke, 1997: 295-300).

\section{- Evaluating the impact of in-service training pro-} grammes

The evaluation techniques/tools should be used as guidelines in the evaluation of in-service training programmes. An adequate number of formal or informal methods of measuring the learning progress of the registered nurses should be employed when evaluating the impact of an in-service training programme (Swansburg, 1996:533). Evaluation of in-service training programmes should address four dimensions which are the outcome of formative evaluation, namely effectiveness, efficiency, nature of the relationship between learning and teaching and user acceptance (Del Bueno in Swansburg, 1995:131).

\section{Recommendations}

The following recommendations, with special reference to nursing education, nursing practice and further nursing research, are based on the findings of this study.

\section{Nursing Education}

Guidelines generated from the findings could be considered in designing in-service training programmes and curricula for the training of registered nurses. Registered nurses should be taught about the importance of in-service training, especially regarding planning, adult learning principles, implementation and evaluation.

\section{Nursing Practice}

Nurses working in units have theoretical knowledge and practical skills related to their profession that could be utilized in the planning and implementation of in-service training programmes. Involvement of competent trainers can have an impact on how the registered nurses experience their practice of nursing. An in-service training committee should be instituted within each department or unit to guide the nurse managers in addressing the needs of registered nurses. These committees could assist in drawing up departmental policies generated from the guidelines proposed in this study with regard to in-service training programmes.

\section{Nursing Research}

There is potential for further study within each identified theme of this research which could provide information to enhance future effectiveness of in-service training programmes. Similar research studies could be conducted in other provinces and comparisons drawn to determine transferability in a wider perspective. However, further research 
regarding the necessary tools or instruments to evaluate in-service training programmes is required.

\section{Limitations}

A comparative study involving presenters [instructors | and recipients [registered nurses] of in-service training programmes could have proven to be more meaningful. This study merely investigated in-service training as experienced by registered nurses in a Primary Health Care setting and not in hospitals. Other important information could possibly have been obtained if registered nurses from both clinics and hospital [ wider research population ] were included or involved in the study.

\section{Conclusion}

This study revealed the complexity of training needs of registered nurses in relation to in-service training programmes. The findings also support the importance of continued in-service training programmes. It is the opinion of the researcher that the guidelines developed, based on the results of this study, should be implemented by the nursing service managers as this can be rewarding and lead to presentation of more effective programmes.

\section{Bibliography}

BEZUIDENHOUT, MC; KOCK,S\& NETSHANDAMA, VO 1999: The role of a ward manager in creating a conducive clinical learning environment for nursing students. Curationis. 22(3):46-52.

BOOYENS, SW 1997: Dimensions of Nursing Management. Cape Town: Juta \& Co.

BOOYENS, SW 1998: Dimensions of Nursing Management. Pretoria: Juta \& Co.

BRINK, HIL 1994: Basic Issues in Clinical Nursing Research. Verpleging RSA Nursing. 9 (8): 14-43.

BURKE, LM 1997: Teachers of nursing - presenting a new model of practice. Journal of Nursing Management. 5:295$3(x)$.

BURNS, N \& GROVE, SK 1993: The Practice of Nursing Research-conduct and utilization. Philadelphia: WB Saunders Co.

BURNS, N \& GROVE, SK 1997: The practice of nursing research, conduct and utilization. Philadelphia: WB Saunders Co.

CARRELL, MR; ELBERT, NF; HATFIELD, RD; GROBLER, PA; MARX, M, \& VAN DERSCHYFF,S 1998: Human Resource Management in South Africa. $1^{\text {s1 }}$ edition. South Africa: Prentice Hall.

CASE, B 1996: Breathing AIR into Adult Learning. The
Joumal of Continuing Education in Nursing. 27 (4): 146-157). CHAMPINHA-BACO'TE,J; YAHLE, T \& LANGENDAMP, M 1996: The Challenge of Cultural Diversity for Nurse Educators. The Journal of Continuing Education in Nursing. $27(2): 59-64$.

COTTON, L 1997: Does Employee Involvement Work? Yes, Sometimes. Journal of Nursing Care Quality. 12 (2):3345.

CRESWELL, JW 1994: Research Design. Qualitative and Quantitative Approaches. Thousand Oakes: Sage.

DE VOS, AS 1998: Research at grassroots. A primer for caring profession. Pretoria: JL van Schaik.

DOUGLAS, LM 1996: The Effective Nurse. Leader and Manager. St. Louis: Mosby.

DU RAND, PP \& VILJOEN, MJ 1999: A Development and Support Programme for Black First Year Nursing Students. Curationis. 22 (3):4-11.

FIELD, PA \& MORSE, J 1996: Nursing Research. The application of qualitative approaches. London: Croon \& Helm.

GERBER, PD; NEI, PS \& VAN DYK, PS 1998: Human Resources Management. $4^{\text {th }}$ edition. Johannesburg: International Thomson Publishing Co.

KERSAITIS, C 1997: Attitudes and Participation of Registered Nurses in Continuing Professional Education in New South Wales, Australia. The Journal of Continuing Education in Nursing. 28 (3): :135-139.

KOTZÉ, WJ 1998: An Anthropological Nursing Science: Nursing Accompaniment Theory. Health SA Gesondheid $3(2)$.

KREFTING, L 1991: Rigor in Qualitative Research: The assessment of Trustworthiness. The American Journal of Occupational Therapy. 45 (3):214-222.

MABEN, F \& ClAARK, M 1996: Making the transition from student to staff nurse. Nursing Times. $44: 28-31$

MASON, J 1996: Qualitative Researching. London: Sage.

MELLISH, JM \& BRINK, H 1990: Teaching the practice of nursing. A text in nursing didactics. $3^{\text {rd }}$ edition. Durban: Butterworth.

POTTER, PA \& PERRY, AG 2001: Fundamentals of Nursing. 5th edition. Philadelphia: Mosby

POGGENPOEL, M 1993: Phenomenological: Interviews Summary. Johannesburg: Rand Afrikaans University. (Unpublished article).

POLIT, DF \& HUNGLER, BP 1997: Essentials of Nursing 
Research. $4^{\text {th }}$ edition. Philadelphia: JB Lippincott Co.

RATH, D; BOBLIN-CUMMINGS, S; BAUMANN, A; PARROTT, E \& PARSONS, M 1996: Individualized Enhancement Programmes for Nurses that Promote Competency. The Journal of Continuing Education in Nursing. 27 (1): 12-15.

SAVAGE, P 1993: Psychiatric nurses' attitudes towards the nursing process. Journal of Nursing management. 1:1924

SOUTH AFRICA (Republic) 1997: Labour Relations Act. (Act 66 of 1997). Pretoria: Government Printers.

SOUTH AFRICAN SOCIETY FOR NURSING RESEARCHERS 1996: Ethical Standards for Nurse Researchers. Curationis. 19(1):74-75.

SOUTH AFRICAN NURSING COUNCIL. Terminology List. 50 YEARS. 1944-1994. Pretoria

STREUBERT, HJ \& CARPENTER, DR 1995: Qualitative Research in Nursing Advancing the humanistic imperative. Philadelphia: J.B. Lippincott Co.

SULLIVAN, EJ \& DECKER, PJ 1992: Effective Management In Nursing. $3^{\text {rd }}$ edition. Menlo Park: Addison-Wesley.

SWANSBURG. RC 1995: Nursing Staff Development. A Component of Human Resource Development. London: Jones \& Bartlett Publishers.

SWANSBURG, RC 1996: Management and Leadership for Nurse Managers. $2^{\text {nd }}$ edition. London: Jones \& Bartlett Publishers.

TALBOT, LT 1994: Principles and practise of nursing research. St. Louis: Mosby.

TUTTY, LM; ROTHERY, MA \& GRINNELL, RM (JR.) 1996: Qualitative research for Social Workers. Phase, steps and tasks. London: Allyn \& Bacon. 